\title{
Kinetic study of Phytase in Four Indian Wheat Varieties (Triticum aestivum L.)
}

\author{
Manish Kumar ${ }^{1,2^{*}}$ and Sushma ${ }^{2}$ \\ ${ }^{1}$ Department of Biochemistry, Institute of Life Science, Bundelkhand University, \\ Jhansi-284128, India \\ ${ }^{2}$ Department of Biochemistry and Biochemical Engineering, Jacob Institute of Biotechnology \\ and Bioengineering, Sam Higginbottom University of Agriculture, Technology and Sciences, \\ Prayagraj-211007, India \\ *Corresponding author
}

\section{A B S T R A C T}

Keywords

Phytase, phytate, wheat, sodium and calcium phytate

Article Info

\section{Accepted:}

15 June 2021

Available Online:

10 July 2021
Phytase (myo-inositol hexakisphosphate phosphohydrolase)enzyme was isolated from wheat varieties to do kinetic study of phytate degradation. The four wheat varieties selected on the basis of their higher phytase activity for investigation were DBW-17, HD-2894, HUW-234 and LOK-1 wheat variety. Among the four selected wheat varieties, LOK -1 variety reported the maximum phytase activity during enzyme kinetics study. Partially purified phytase had $\mathrm{pH}$ optima at $\mathrm{pH} 5.0$ with temperature optima at $60^{\circ} \mathrm{C}$, which showed maximal phytate degrading activity. The enzyme was found to have good substrate specificity for sodium phytate at $3 \mathrm{mM}$ and calcium phytate at $2 \mathrm{mM}$ concentration. Wheat phytase can be used in hydrolysis of phytate in food industries for releasing micronutrients and enhance increasing their bioavailability to chemical industry as well.

\section{Introduction}

Phytic acid (myo-inositol 1, 2, 3, 4, 5, 6 hexakis dihydrogen phosphate) widely occurs in plant foods, such as cereals, legumes, fruits and vegetables. It represents $50-85 \%$ of the total phosphorus in plant seeds (Pallauf and Rimbach, 1997). At neutral $\mathrm{pH}$, phytic acid in foods is negatively charged and has capacity to bind proteins and cations including $\mathrm{Ca}^{2+}$, $\mathrm{Fe}^{2+}, \mathrm{Zn}^{2+}, \mathrm{Mg}^{2+}$, resulting in low bioavailability of bound components (Liang et al., 2008). Phytic acid can be degraded by phytase, both occurring as endogenous enzyme in seeds and accumulated during germination, or as exogenous microbial enzyme (Duhan et al., 2001). Endogenous phytase in grains plays an important role in the 
utilization of nutrients by the embryo during germination of seeds and growth of plants (Reddy et al., 1978; Mulimani et al., 2003). Phytase will be activated and accumulates during seed germination, and acts on phytic acid (Murugkar and Jha, 2009). It releases inorganic phosphate, which is then utilized for plant growth, and serves as a natural buffer in grains as well.

Germination of seeds or pollen leads to a rapid disappearance of phytin inclusions accompanied by a large increase in activity of the enzyme responsible for phytin degradation, phytase (Gibson and Ullah, 1990). Seeds contain both constitutive phytase activity and phytases that are synthesized de novo during germination (Nayini and Markakis, 1986). Most seed phytases which have been studied to date belong to a special class of non-specific acid phosphatases with optimal activity between $\mathrm{pH} 4.0$ and 5.6.

In addition to phytic acid hydrolysis, these enzymes are able to hydrolyze a variety of natural and synthetic phosphate esters. In terms of the rate of hydrolysis, phytic acid has occasionally been shown to be one of the poorer substrates for seed phytase (Lolas and Markakis, 1977; Mandal et al., 1972).

\section{Materials and Methods}

Four locally available wheat varieties were purchased from Alopibagh market, Prayagraj, India to carried out the work, which are namely DBW-17, HD-2894, HUW-234 and LOK-1.

\section{Phytase assay}

$0.5 \mathrm{~g}$ fresh samples of all wheat varieties were separately homogenized in $10 \mathrm{ml}$ of sodium acetate buffer (0.1M, $\mathrm{pH}$ 5.0). The homogenized samples were centrifuged at $12000 \mathrm{~g}$ for $5 \mathrm{~min}$ and supernatants were used for enzyme assay (Senna et al., 2006). The assay mixture consisted of $350 \mu 1$ of sodium acetate buffer $(0.1 \mathrm{M}, \mathrm{pH} 5.0)$ and $100 \mu \mathrm{l}$ of sodium phytate $(2 \mathrm{mM})$. This mixture was preincubated for $10 \mathrm{~min}$ at $40^{\circ} \mathrm{C}$ and the enzymatic reactions were started by adding $100 \mu 1$ of the crude enzyme to preincubated assay mixture.

After incubation at $40^{\circ} \mathrm{C}$ for $30 \mathrm{~min}$, the liberated phosphate was measured by using the ammonium molybdate. For this, to the assay mixture, $1.5 \mathrm{ml}$ of a freshly prepared solution of acetone $/ 5 \mathrm{~N} \quad \mathrm{H}_{2} \mathrm{SO}_{4} / 10 \mathrm{mM}$ ammonium molybdate $(2: 1: 1 \quad \mathrm{v} / \mathrm{v} / \mathrm{w})$ and $100 \mu \mathrm{l}$ of $1.0 \mathrm{M}$ citric acid were added. Any cloudiness was removed by centrifugation to measurement of the absorbance at $355 \mathrm{~nm}$ against blank as ammonium molybdate solution (Heinonen and Lahti, 1981).

\section{Kinetics Study of phytase enzyme}

Selected four wheat varieties were checked for phytase activity at different $\mathrm{pH}(3,5,7,9$ and $11)$ in sodium acetate buffer $(0.1 \mathrm{M})$ to optimize the $\mathrm{pH}$. The temperature profile of the purified phytase was determined at different temperatures $(20,40,60,80$ and $100^{\circ} \mathrm{C}$ ) using the standard phytase assay.

Thermal stability of the purified enzyme was assayed. The effects of substrates on enzyme activity were investigated by pre-incubating the compounds with the purified phytase for $15 \mathrm{~min}$ at $37^{\circ} \mathrm{C}$ before the standard phytase assay was performed. The substrates (sodium phytate and calcium phytate) were used in concentrations of $1,2,3,4$ and $5 \mathrm{mM}$ for phytase kinetics.

\section{Statistical analysis}

The data were analyzed by SPSS ver. 20.0, two-way analysis of variance (ANOVA) at 5\% level of significance. 


\section{Results and Discussion}

\section{Enzyme kinetics of phytase}

Under this, effect of $\mathrm{pH}$, temperature and different substrates concentration (sodium phytate and calcium phytate) were checked on phytase activity of four selected wheat varieties.

\section{Effect of pH on Phytase Activity}

Effect of $\mathrm{pH}$ on phytase activity was studied at $3,5,7,9$ and $11 \mathrm{pH}$ in four wheat varieties from Fig.-1, but maximum phytase activity was observed in LOK-1 wheat variety in all different $\mathrm{pH}(\mathrm{pH} 3-138.21 \pm 0.17$; $\mathrm{pH} 5$ $447.17 \pm 0.42$; $\mathrm{pH} 7$ - 356.42 $\pm 0.21 ; \mathrm{pH} 9$ $215.17 \pm 0.09 ; \mathrm{pH} 11-121.18 \pm 0.10 \mathrm{nM} / \mathrm{min} / \mathrm{g}$ ) followed by DBW-17, HD-2894 and HUW234 wheat varieties, respectively. Wheat phytase showed optimal activity at $\mathrm{pH} 5.0$ (Nakano et al., 1999). Phytase enzyme from various origin have different optimal $\mathrm{pH}$ and temperature for example, an optimum $\mathrm{pH} 5.5$ at $55^{\circ} \mathrm{C}$ has been reported for wheat phytase (Leenhardt et al., 2005) whereas, optimum temperature and $\mathrm{pH}$ for rye phytase is 6.0 and $45^{\circ} \mathrm{C}$, respectively (Greiner et al., 1998). Shoot and root phytase of maize addressed as acid phytases because of their optimal activity at $\mathrm{pH} 5.0$ (Laboure et al., 1993). The $\mathrm{pH}$ optima of plant seed phytases range from 4.0 to 7.5, but most fall between 4.0 and 5.6. Two alkaline plant phytases having $\mathrm{pH}$ optima around 8.0 have been described from legume seeds (Scott, 1991) and lily pollen (Hara et al., 1985); acidic phytases with a $\mathrm{pH}$ optimum around 5.0, and alkaline phytases with an optimum around 8.0. The first group includes the soybean seed phytase (Gibson and Ullah, 1988), the Fl phytase of wheat bran (Lim and Tate, 1971 and 1973), the $\mathrm{pH} 5.0$ phytases of Lilium longiflorum pollen (Baldi et al., 1988) and of Petunia hybrida pollen (Jackson and Linskens, 1982). Acidic phytases exhibit a broad affinity for various phosphorylated substrates (Gibson and Ullah, 1990), and the wheat bran $\mathrm{pH} 5.0$ phytase catalyses the hydrolysis of virtually all intermediate forms of myo-inositol phosphate from phytic acid to myo-inositol 2-phosphate (Lim and Tate, 1971).

\section{Effect of temperature on phytase activity}

Effect of temperature on phytase activity was studied at $20^{\circ} \mathrm{C}, 40^{\circ} \mathrm{C}, 60^{\circ} \mathrm{C}, 80^{\circ} \mathrm{C}$ and $100^{\circ} \mathrm{C}$ for four selected wheat varieties from Fig. 2. But maximum phytase activity was observed in LOK-1 wheat variety in all different temperature $\left(20^{\circ} \mathrm{C}-246.23 \pm 0.44 ; 40^{\circ} \mathrm{C}\right.$ $343.18 \pm 0.11 ; 60^{\circ} \mathrm{C}-364.05 \pm 0.03 ; 80^{\circ} \mathrm{C}-$ $137.03 \pm 0.35$ and $100^{\circ} \mathrm{C}-71.33 \pm 0.71$ $\mathrm{nM} / \mathrm{min} / \mathrm{g}$ ) followed by DBW-17, HD-2894 and HUW-234 wheat varieties, respectively. Optimal temperatures of most phytases vary from 37 to $77^{\circ} \mathrm{C}$ (Hara et al., 1985). In contrast, wheat phytase maintained more than $50 \%$ of its highest activity relatively at 30 to $80^{\circ} \mathrm{C}$ with an optimum of $50^{\circ} \mathrm{C}$ (Inkyung and Jaiesoon, 2012). Although enzymes obtained from microorganisms inhabiting cold environments such as polar regions and deep sea show higher catalytic efficiency at low temperatures than their mesophilic counterparts (Gerday et al., 1997). Phytase, sensitive to high temperature and pressure, is not heat stable and should be applied by avoiding excess heat during extrusion, which may destroy the phytase effect. Similarly high temperatures $\left(>70^{\circ} \mathrm{C}\right)$ caused partial or total inactivation of native phytase. Most phytases have an optimal $\mathrm{pH}$ in the range of 4.5-6.0 and a temperature range of $45-60^{\circ} \mathrm{C}$. Outside the optimal range of $\mathrm{pH}$ and temperatures the action of phytase is reduced (Lei and Stahl, 2000). 
Fig. 1 Effect of pH on phytase activity

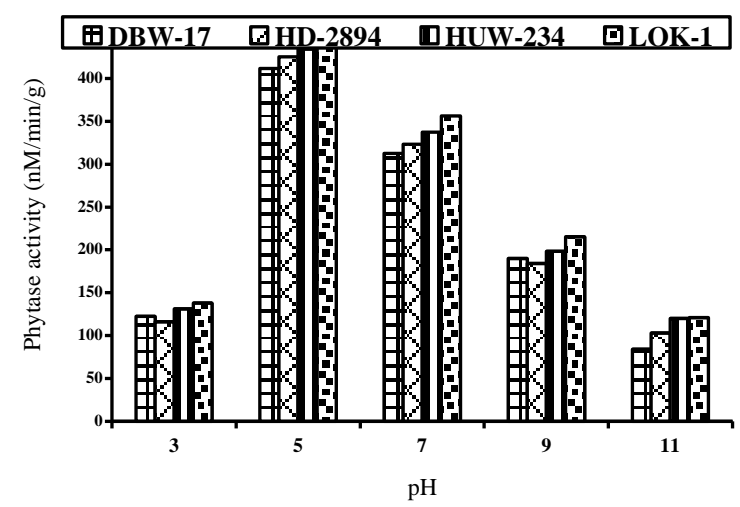

Fig. 3 Effect of sodium phytate on phytase activity

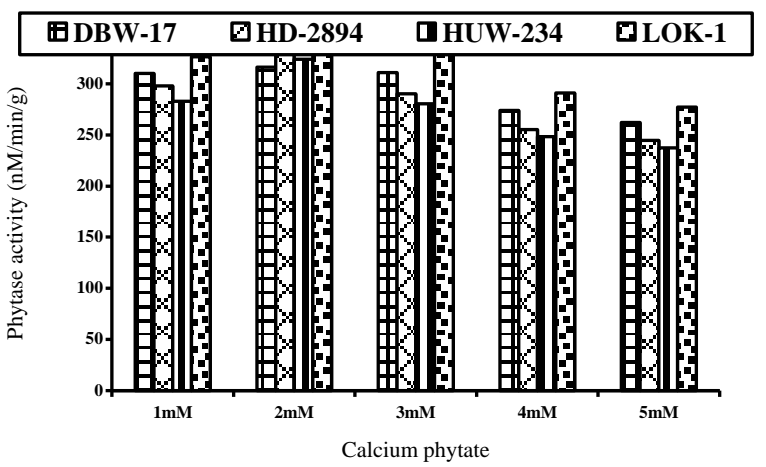

Effect of sodium phytate on phytase activity

Effect of sodium phytate on phytase activity was studied at 1, 2, 3, 4 and $5 \mathrm{mM}$ in four selected wheat varieties Fig. 3. But maximum phytase activity was observed in LOK-1 wheat variety at different sodium phytate concentrations $(1 \mathrm{mM}-432.45 \pm 0.24 ; 2 \mathrm{mM}$ $459.41 \pm 0.30 ; 3 \mathrm{mM}-488.27 \pm 0.27 ; \quad 4 \mathrm{mM}-$ $439.31 \pm 0.17$ and $5 \mathrm{mM}-\quad 402.07 \pm 0.07$ $\mathrm{nM} / \mathrm{min} / \mathrm{g}$ ) followed by DBW-17, HD-2894 and HUW-234 wheat varieties, respectively. A. ficuum and wheat phytase showed broader specificity for phytate and various other phosphate compounds. Furthermore, A.ficuum phytase was 4-fold less active against sodium phytate compared to magnesium phytate, while wheat phytase equally hydrolyzed these two substrates. Interestingly, the wheat enzyme hydrolyzed ATP 5.4-fold higher than phytate substrates, which supports the fact that
Fig. 2 Effect of temperature on phytase activity

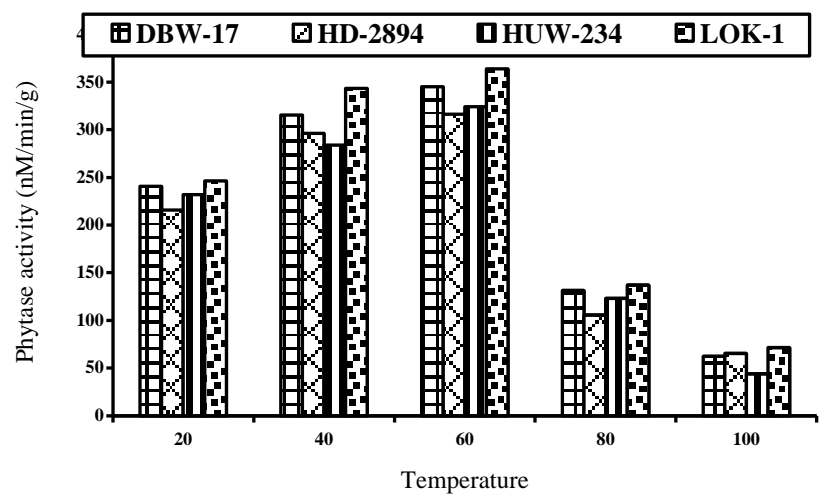

Fig. 4 Effect of calcium phytate on phytase activity

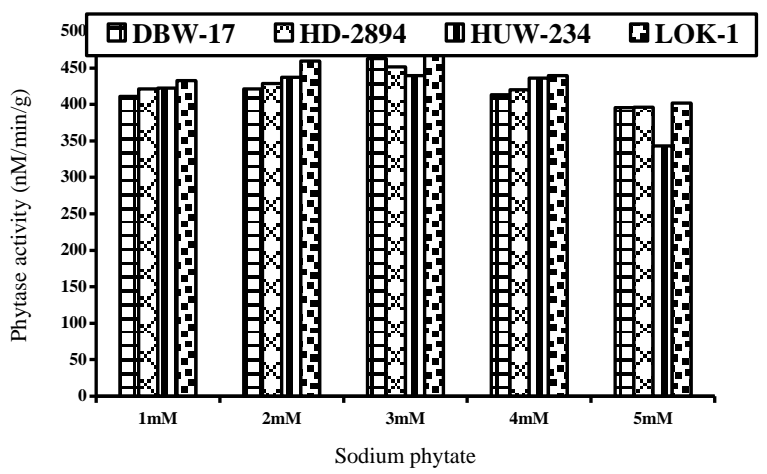

phytate-degrading enzymes from plants generally yield the highest relative rates of hydrolysis with substrate specificity for phytate (Inkyung and Jaiesoon, 2012). Most probably, purification resulted in removing some acid phosphatase activity present in crude extracts, and consequently less acid phosphatase was acting on sodium phytate during activity determination. On the other hand, both phytase and acid phosphatase were active in dephosphorylating plant phytates in wheat samples subjected to in vitro digestions. Apparently, in the dephosphorylation processes the contribution of phytatedegrading enzymes other than phytase present in wheat is more notable in degrading sodium phytate than during their action on plant phytates (Zyra et al., 1999).

\section{Effect of calcium phytate on phytase activity}


Effect of calcium phytate on phytase activity was studied at 1, 2, 3, 4 and $5 \mathrm{mM}$ in four selected wheat varieties from Fig. 4. But maximum phytase activity was observed in LOK-1 wheat variety at different calcium phytate concentration (1mM - 326.28 \pm 0.15 ;

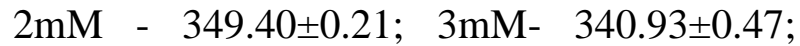
$4 \mathrm{mM}-291.11 \pm 0.11$ and $5 \mathrm{mM}-277.23 \pm 0.23$ $\mathrm{nM} / \mathrm{min} / \mathrm{g}$ ) followed by DBW-17, HD-2894 and HUW-234 wheat varieties, respectively. Alkaline phytase activity with $\mathrm{pH} 8$, was recovered from detergent extracts of dormant seeds of nine varieties of Phaseolus vulgaris L., Pisum sativum L. var. Early Alaska, and Medicago sativa L. This alkaline phytase of legume seeds was activated by calcium and differed from most seed phytases in its relative insensitivity to inhibition by fluoride (Scott, 1991). The essential minerals of concern in human nutrition, which may be affected by phytate are calcium, copper, iron, and zinc (Janghorbani and Ting, 1990). The absorption and bioavailability of indispensable minerals such as calcium, zinc, magnesium, and iron may also be negatively affected by forming insoluble chelate complexes with phytate (Papatryphon et al., 1999). Phytate can also combine protein and vitamin as insoluble complexes to reduce their utilization efficiency, activity and digestibility (Liu et al., 1998; Sugiura et al., 2001). In vitro studies have shown that phytate-protein complexes are less attacked by proteolytic enzymes (Ravindran et al., 1995); even some enzymes such as pepsin, amylopsin, and amylase would be inhibited by phytate. Furthermore, phytate may interfere with the digestibility of lipid and starch (Cosgrove, 1966).

The data obtained in this study indicate that significant differences were observed in phytase activity of different wheat varieties in enzyme kinetic study. Phytase activity significantly increases in LOK-1 wheat variety with acidic $\mathrm{pH}$ but decreases in basic $\mathrm{pH}$ with optimum temperature $60^{\circ} \mathrm{C}$ and both substrates are good in their substrate specificity with phytase enzyme at $3 \mathrm{mM}$ of sodium phytate and $2 \mathrm{mM}$ of calcium phytate, when increases the concentration of both substrates then significantly decreases phytase activity in all wheat varieties were observed. Such noble phytase can be study in cosmetic and food industry for their several beneficial prospectuses.

\section{Acknowledgement}

We are thankful to Head of Department of Biochemistry and Biochemical Engineering and Dean of Jacob Institute of Biotechnology \& Bioengineering, Sam Higginbottom University of Agriculture Technology and Sciences, Prayagraj for providing all necessary facilities to conduct the experiment in research laboratory.

\section{References}

Baldi, B. G., Scott, J. J., Everard, J. D., and Loewus, F. A. 1988. Localization of constitutive phytases in lily pollen and properties of the $\mathrm{pH} 8$ form. Plant Science, 56 (2), 137-147.

Cosgrove, D. J. 1966. The chemistry and biochemistry of inositol polyphosphates. Reviews of pure and applied chemistry, 16: 209-224.

Duhan, A., Khetarpaul, N. and Bishnoi, S. 2001. Effect of soaking, germination and cooking on phytic acid and hydrochloric acid extractability of a pigeonpea cultivar. $J$ Food $S c i$ Technol, 38: 374-378.

Gibson, D. M. and Ullah, A. H. J. 1988. Purification and characterization of phytase from cotylendons of germinating soybean seeds. Archives of Biochemistry and Biophysics, 260(2): 503-513.

Gibson, D. M. and Ullah, A. B. J. 1990. 
Phytases and their action on phytic acid. Zn, D. J. Morre, W. F. Boss, F. A. Loewus, eds, Inositol Metabolism in Plants. Wiley-Liss, New York, pp 77-92.

Greiner, R., Konietzny, U. and Jany, K. D. 1998. Purification and properties of a phytase from rye. Journal of Food Biochemistry, 22(2): 143-161.

Gerday, C., Aittaleb, M., Arpigny, J. L., Baise, E., Chessa, J. P., Garsoux, G., Petrescu, I. and Feller, G. 1997. Psychrophilic enzymes: a thermodynamic challenge. Biochimica et Biophysica Acta, 1342(2): 119-131.

Hara, A., Ebina, S., Kondo, A. and Funaguma, T. 1985. A new type of phytase from pollen of Typha latifolia L. Agricultural and Biological Chemistry, 49: 3539-44.

Inkyung Park and Jaiesoon Cho 2012. The phytase from antarctic bacterial isolate, Pseudomonas sp. JPK1 as a potential tool for animal agriculture to reduce manure phosphorus excretion. African Journal of Agricultural Research, 6(6): 1398-1406.

Jackson, J. F. and Linskens, H. F. 1982. Phytic acid in Petunia hybrida pollen is hydrolyzed during germination by a phytase. Acta Botanica Neerlandica, 31(5-6): 441-447.

Janghorbani, M. and Ting, B. T. G. 1990. Stable isotope methods for studies of mineral/trace element metabolism. Journal of Nutritional Biochemistry, 1(1): 4-19.

Lim, P. E. and Tate, M. E. 1971. The phytases: 1- Lyso-lecithin-activated phytase from wheat bran. Biochimica et Biophysica Acta,250: 155-164

Lim, P. E. and Tate, M. E. 1973. Phytases: 2Properties of phytase fractions $F_{1}$ and $\mathrm{F}_{2}$ from wheat bran and myo-inositol phosphates produced by fraction $\mathrm{F}_{2}$. Biochimica et Biophysica Acta,
302(2): 316-328.

Liang, J., Han, B., Nout, M. J. R. and Hamer, R. J. 2008. Effects of soaking, germination and fermentation on phytic acid, total and in vitro soluble zinc in brown rice. Food Chem, 110: 821-828.

Lei, X. G. and Stahl, C. H. 2000. Nutritional benefits of phytase and dietary determinants of its efficacy. Journal of Applied Animal Research, 17(1): 97112.

Liu, B. L., Rafing, A. and Tzeng, Y. M. 1998. The induction and characterization of phytase and beyond. Enzyme and Microbial Technology, 22(5): 415424.

Leenhardt, F., Levrat-Verny, M. A., Chanliaud, E. and Reameasy, C. 2005. Moderate decrease of $\mathrm{pH}$ by sourdough fermentation is sufficient to reduce phytate content of whole wheat flour through endogenous phytase activity. Journal of Agricultural and Food Chemistry, 53(1): 98-102.

Lolas, G. M. and Markakis, P. 1977. The phytase of navy beans (Phaseolus vulgaris). J Food Sci, 42: 1094-1106

Laboure, A. M., Gagnon, J. and Lescure, A. M. 1993. Purification and characterization of a phytase (myoinositol-hexakisphosphate phosphohydrolase) accumulated in maize (Zea mays) seedlings during germination. Biochemical Journal, 295(2): 413-419

Mandal, N. C., Burman, S. and Biswas, B. B. 1972. Isolation, purification and characterization of phytase from germinating mung beans. Phytochemistry, 11: 495-502

Mulimani, V. H., Kadi, N. S. and Thippeswamy, S. 2003. Effect of processing on phytic acid content in different red gram (Cajanus cajan L.) varieties. J Food Sci Technol, 40: 371- 
373.

Murugkar, D. A. and Jha, K. 2009. Effect of sprouting on nutritional and functional characteristics of soybean. J Food Sci Technol, 46: 240-243.

Nayini, N. R. and Markakis, P. 1986. Phytases. In E. Graf, ed, Phytic Acid: Chemistry and Applications. Pilatus Press, Minneapolis, pp 101-118.

Nakano, T., Joh, T. T., Okumoto, E. and Hayakama, T. 1999. Purification and characterization of phytase from bran of Triticum aestivum L. cv.Nourin \#61Food Science and Technology Research, 5(1): 18-23.

Papatryphon, E., Howell, R. A. and Soares, J. H. 1999. Growth and mineral absorption by striped bass Morone saxatilis fed a plant feedstuff based diet supplemented with phytase. World Aquaculture Society, 30(2): 161-173.

Pallauf, J. and Rimbach, G. 1996. Nutritional significance of phytic acid and phytase. Archive of Animal Nutrition,
50(4): 301-319.

Ravindran, V., Bryden, W. L. and Kornegay, E. T. 1995. Phytates: occurrence, bioavailability, and implications in poultry nutrition. Poultry and Avian Biology Reviews, 6: 125-143.

Reddy, N. R., Balkrishnan, C. V. and Salunkhe, D. K. 1978. Phytate phosphorus and mineral changes during germination and cooking of black gram (Phaseolus mungo) seeds. J Food Sci, 43: 540-544.

Scott, J. J. 1991. Alkaline phytase activity in non-ionic detergent extracts of legume seeds. Plant Physiology, 95(4): 12981301.

Sugiura, S. H., Gabaudan, J., Dong, F. M. and Hardy, R. W. 2001. Dietary microbial phytase supplementation and the utilization of phosphorus, trace minerals and protein by rainbow trout [Oncorhynchus mykiss] (Walbaum) fed soybean meal-based diets. Aquaculture Research, 32(7): 583-592.

\section{How to cite this article:}

Manish Kumar and Sushma. 2021. Kinetic study of Phytase in Four Indian Wheat Varieties (Triticum aestivum L.). Int.J.Curr.Microbiol.App.Sci. 10(07): 371-377. doi: https://doi.org/10.20546/ijcmas.2021.1007.040 